\title{
Impact of Temporal Population Distribution on Earthquake Loss Estimation: A Case Study on Sylhet, Bangladesh
}

\author{
Sharmin Ara
}

Published online: 11 December 2014

(C) The Author(s) 2014. This article is published with open access at Springerlink.com

\begin{abstract}
To estimate human loss in an earthquake-prone area, it is necessary to analyze the role played by the spatiotemporal distribution of the area's resident population. In order to evaluate earthquake impact, this article focuses on the spatiotemporal distribution of population and five scenario earthquakes that form the basis for loss estimation in the city of Sylhet, Bangladesh. Four temporal contexts (weekday, weekly holiday, the 30 days of Ramadan, and strike days) expand the more typical daytime and nighttime settings in which to examine hazard risk. The population distribution for every 2 hour interval in a day is developed for each type of day. A relationship between the occupancy classes and average space (persons per $100 \mathrm{~m}^{2}$ ) is used to distribute people in each building regardless of building locations. A total daytime and nighttime population is obtained for each building and the estimated nighttime population is used to model the population for four temporal scenarios in a year based on different factors and weights. The resulting data are employed to estimate population loss for each of the temporal and earthquake scenarios. This study used building-specific human vulnerability curves developed by the Central American Probabilistic Risk Assessment (CAPRA) to obtain possible loss of life estimates. The results reveal that there is a high positive correlation between the spatiotemporal distribution of population and the potential number of casualties.
\end{abstract}

\section{S. Ara $(\bowtie)$}

Department of Urban and Regional Planning, Chittagong

University of Engineering and Technology, Chittagong 4349, Bangladesh

e-mail: ara28457@alumni.itc.nl
Keywords Bangladesh · CAPRA · Distribution modeling $\cdot$ Earthquake loss estimation - Spatiotemporal population distribution $\cdot$ Temporal scenarios

\section{Introduction}

Bangladesh is exposed to frequent damaging earthquakes because it is surrounded by high seismicity regions (Ansary 2002). Historical data show that the northeastern region (especially Sylhet, Mymensingh, and Rangpur) has experienced frequent earthquakes and incurred enormous damage (Ansary and Islam 2008). In this situation loss assessment studies are an effective tool for risk analysis and emergency management estimation of the probable loss of human lives and properties. According to the United Nations International Strategy for Disaster Reduction (UNISDR 2009), disaster risk can be defined as the probability of losses. This can also be expressed as a function of hazard, vulnerability, and elements at risk (property, infrastructure, human life, and so on). Human existence involves exposure to many hazards (Jonkman et al. 2003). Population exposure refers to human occupancy near or presence within the hazard-prone area and thus the population that would be potentially affected by an event (Freire and Aubrecht 2012). Accurate estimation of population exposure is a key component for probable loss estimation (Chen et al. 2004; Aubrecht et al. 2012). In a densely populated urban area, due to human activities, the distribution of people depends on the time of a day. Population distribution and density are very different in a daytime as opposed to a nighttime situation. Therefore it is necessary to analyze the impact of the temporal distribution of the population living in an earthquake-prone area to achieve a realistic assessment. Researchers now emphasize carrying 
out earthquake loss estimations for different temporal cycles of a day. Alexander (1996) concluded that the risk of injury varies significantly between night and day when an earthquake occurs, which leads to the recommendation that vulnerability and exposure should be assessed in this temporal cycle (Freire and Aubrecht 2012). For better and more effective disaster management and planning it is crucial to consider variations in population distribution over time. Detailed population distribution mapping not only helps in risk assessment but also supports other phases of disaster management (Aubrecht et al. 2012).

Risk assessment can be done in a qualitative, semiquantitative, or quantitative manner. The suitability of a particular assessment approach depends on the available input data, required results, and the nature of the risk problem (Dai et al. 2002). Quantitative risk estimates provide the input for risk evaluation and decision making. This quantitative estimate is usually expressed as a combination of probabilities and consequences derived from a range of possible accident scenarios, which can be used as a basis for cost-benefit analysis. For risk evaluation and decision-making, potential loss of life plays an important role (Jonkman et al. 2003, 2010). Different damage and loss estimation techniques are used to quantify the potential social and economic losses from an earthquake. These quantification processes are very complex but are a useful tool for developing an emergency preparedness plan and reducing future seismic risk (Agrawal and Ajay 2004). Loss estimation can be done by methods using GIS and remote sensing techniques (Chen et al. 1998), GDP and population distribution data (Chen et al. 1997; Dunbar et al. 2003), as well as specialized computer-based modeling approaches. These methodologies provide basic information about the physical, social, and economic losses caused by an earthquake. High-resolution satellite imagery, with a high level of detail, makes it possible to detect reliably dwelling and other infrastructure damage (Chiroiu and André 2001). Kerle (2012) and Zhang and Kerle (2008) conducted extensive work on remote sensing-based damage assessment for earthquakes and other natural and manmade hazards. However the satellite imagery-based extraction of dwellings can only indicate the presence of people at the moment of data capture. The number of people living in the visible dwelling structures is uncertain; as a consequence, the associated population loss estimation becomes ambiguous (Lang et al. 2010). In addition to building damage assessment, loss estimation studies that model the spatial and temporal distribution of population in an urban area will provide more accurate information to the authorities. These studies also include crucial data on the impact of different possible scenarios that account for earthquake sources, the time of day when the earthquake may hit, and the size of populations exposed to risk. Better information makes it possible to design more effective emergency response plans and risk reduction strategies.

The aims of the present work are (1) to locate accurately the people occupying specific buildings and (2) to identify the impact of this distribution on probable population loss over four different temporal scenarios for Sylhet City in northeastern Bangladesh. In addition to a daytime and nighttime scenario, weekday, weekly holiday, strike day, and Ramadan scenarios, which have very different population distribution patterns in the city, are also evaluated.

\section{Population Distribution and Loss Estimation Techniques for Earthquake Risk Assessment}

It is highly important to know the spatial location of people to understand the impact of any natural disaster. For damage assessment, especially for unpredictable and rapid onset hazards such as earthquakes, detailed building inventory databases with population data are essential (Freire 2010). Updated and detailed spatial and temporal population distribution data for an area will also be useful for disaster risk mitigation, preparedness, response, recovery, and rehabilitation (Freire 2010; Freire and Aubrecht 2012; Sutton et al. 2003).

Population distribution in an urban area is directly related to their mobility, activity, and functionality. Based on this notion, Bhaduri et al. (2007) adopted a new approach to estimate the distribution of population. This method considers the possible number of workers, students attending school, tourists, and travelers in a city context. The methodology also depends on the distribution of major demographic groups in the area. Du et al. (2006) also analyzed the causes and characteristics of population distribution in urban areas. Their statistical analysis shows that the distribution of different public sector facilities (for example, school, college, hospital, market, government office) and infrastructure also influence population distribution. Besides these approaches, Freire and Aubrecht (2012) introduced dasymetric mapping to disaggregate the population census data for daytime and nighttime in the metropolitan area of Lisbon, Portugal. Their goal was to analyze variable spatiotemporal exposure of the population to earthquake hazard. A recently developed new approach from the cellular network data can also be used for population distribution modeling (Pulselli et al. 2008). The distribution of people in space is time dependent but it is possible to display this dispersion geographically in space and time (Becker et al. 2011). Table 1 briefly summarizes different spatial and temporal population distribution modeling approaches, their data requirements, and techniques.

Earthquakes are the most unpredictable natural hazard. The quake occurs almost instantaneously, but the impact 
Table 1 Population distribution modeling approach

\begin{tabular}{|c|c|c|c|c|}
\hline Category & Methods & & Data requirements & Techniques \\
\hline \multirow[t]{2}{*}{$\begin{array}{l}\text { Cartographic } \\
\text { method }\end{array}$} & $\begin{array}{l}\text { Choroplethic } \\
\text { mapping }\end{array}$ & & Population census data & $\begin{array}{l}\text { Divides the total population by the total land } \\
\text { area }\end{array}$ \\
\hline & $\begin{array}{l}\text { Dasymetric } \\
\text { mapping }\end{array}$ & & Population census data, land-use data & $\begin{array}{l}\text { Divides the areas into smaller spatial units (using } \\
\text { ancillary land use data) where the population is } \\
\text { averaged to obtain the density }\end{array}$ \\
\hline \multirow{4}{*}{$\begin{array}{l}\text { Surface based } \\
\text { model }\end{array}$} & \multirow{4}{*}{$\begin{array}{l}\text { Areal } \\
\text { interpolation }\end{array}$} & \multicolumn{3}{|c|}{ Without ancillary data } \\
\hline & & $\begin{array}{l}\text { Point } \\
\text { based }\end{array}$ & Population census data & $\begin{array}{l}\text { Simple areal weighting, population-weighted } \\
\text { centroids with a distance decay function }\end{array}$ \\
\hline & & $\begin{array}{l}\text { Area } \\
\text { based }\end{array}$ & & $\begin{array}{l}\text { Pycnophylactic interpolation assumes a smooth } \\
\text { density function that takes into account the } \\
\text { effect of adjacent source zones while } \\
\text { preserving its volume }\end{array}$ \\
\hline & & $\begin{array}{l}\text { With } \\
\text { ancillary } \\
\text { data }\end{array}$ & $\begin{array}{l}\text { Population census data, land-use data, } \\
\text { transportation network data }\end{array}$ & Same as dasymetric mapping approach \\
\hline $\begin{array}{l}\text { Statistical } \\
\text { model }\end{array}$ & $\begin{array}{l}\text { Statistical } \\
\text { modeling }\end{array}$ & & $\begin{array}{l}\text { Socioeconomic variables, remote sensing } \\
\text { images, population census data } \\
\text { (indirectly) }\end{array}$ & $\begin{array}{l}\text { Reveal the relationship between urban areas; } \\
\text { land use; dwelling unit; image pixel } \\
\text { characteristics; physical and socioeconomic } \\
\text { characteristics }\end{array}$ \\
\hline $\begin{array}{l}\text { Spatiotemporal } \\
\text { (LandScan } \\
\text { USA model) }\end{array}$ & $\begin{array}{c}\text { Dasymetric } \\
\text { modeling }\end{array}$ & & $\begin{array}{l}\text { daytime population, nighttime residential } \\
\text { population, worker, student, tourist, and } \\
\text { traveler data, land-use data, satellite } \\
\text { imagery }\end{array}$ & $\begin{array}{l}\text { Census blocks divided into grid cells } \\
(30 \mathrm{~m} \times 30 \mathrm{~m}) \text {; total population for the block } \\
\text { is allocated to the cells with weights } \\
\text { proportional to the calculated likelihood of } \\
\text { being populated }\end{array}$ \\
\hline
\end{tabular}

Source Holt et al. (2004), Wu et al. (2005) and Bhaduri et al. (2007)

lasts for a long time and causes great human losses (injury, death, and property damage). Some disasters (for example fires or explosions) have an impact area that is as small as a neighborhood or even a single building. Therefore it is essential to know the spatial and temporal distribution of the population at a fine resolution in order to estimate hazard impacts. The National Research Council (NRC) stated that the quality and level of population data have a direct effect on the effective performance and number of lives saved by a disaster response (Freire and Aubrecht 2012). Building level data are able to provide a more detailed population database than the data sets developed for gridded population dynamic models. There are different components in population loss estimation, such as estimation of deaths and injuries, homelessness, or postdisaster displacement (Dunbar et al. 2003).

Spence and So (2009) classified the available earthquake population loss estimation into three estimation methods: empirical, semiempirical, and analytical. The empirical approach consists mainly of simple correlations of casualties inflicted upon the population exposed to an earthquake and its estimated ground-shaking intensity. Empirical approaches only make gross assumptions and eliminate many of the explanatory variables. A semiempirical approach estimates damage rates for different building types in the study area and then shows a relationship between the casualty rates (death and injury) and each building type. This approach takes into account the effect earthquakes have on different building types by climatic zone, urban/rural location, culture, income level, and so on, as well as the way building types are mixed together. A semiempirical method also factors in local characteristics of search and rescue and post-rescue treatment capability. Analytical methods predict the behavior of buildings in earthquakes and therefore determine the effects of quakes on the people who are inside the building. This method does not take into account the behavior of nonengineered buildings in earthquake-prone areas of the world where the impacts on humans are extensive.

The output of all three approaches is quantitative and for this GIS, remote sensing techniques, and specialized computer-based modeling approaches are widely used (Chen et al. 1998; Chiroiu and André 2001; Chiroiu 2005). There are different computer-based modeling approaches ${ }^{1}$ that are well known and extensively used based on the requirements and zone of a particular study (IDNDR 1999; FEMA 2003; Elnashai and Hajjar 2006; Hancilar et al. 2010; Jaiswal et al. 2011; CAPRA 2012; GEM 2012). This study uses the Central American Probabilistic Risk

\footnotetext{
${ }^{1}$ For example, GEM, CAPRA, HAZUS-MH, RADIUS, ELER, MAEviz, PAGER, and NHEMATIS.
} 
Assessment (CAPRA) model, a recently developed methodology that was introduced for multihazard probabilistic and deterministic risk assessment. CAPRA has different modules for different hazard assessments and includes hazard mapping, risk analysis, and vulnerability modules. The vulnerability module, called ERN-vulnerability, is composed of a large number of vulnerability curves (building and human) and helps to calculate population casualties directly by using human vulnerability curves for different building types and quake intensity level. There are many factors that influence the resulting shape of the curves and users can change the value of those factors. This approach estimates population loss in one step. It does not take into account the building damage information, but it does require detailed information about the building structure. In the risk module, CAPRA-GIS is used to calculate the potential losses for different return periods and specific earthquake scenarios. It gives the result in a probable maximum loss (PML) curve for the population in different return periods (CAPRA 2012). This research uses the vulnerability curves from the ERN-vulnerability package of CAPRA to estimate loss of life. These methodologies for loss estimation help urban planners, civil engineers, and policy makers to carry out risk evaluation as a basis for the management and mitigation of natural disaster risks such as earthquakes.

\section{Study Area}

Bangladesh is divided into three earthquake zones based on the probable ground motion and consequent damage. Among these zones, zone I is most active (HBRI-BSTI 1993) and Sylhet is located in this zone. The total area of the Sylhet District is $3,490 \mathrm{~km}^{2}$ and the area of the city is $57.64 \mathrm{~km}^{2}$. There are 27 administrative units-wards-in this city (Fig. 1). According to the census of 2011, the total population of Sylhet district was $3,434,188$, and the population of the city was 479,837 . The average household size was 4.8 in the city but in wards 12,25 , and 27 the household size was 5.3. The estimated number of buildings in the city was almost 52,000 (CDMP 2009). Census data and other statistical reports illustrate that there is an increasing trend of population growth in Sylhet City. In 2001 the total population was 262,899 , and it increased to 479,837 in 2011 . The main reasons behind this high urban population growth are the high rate of remittance from expatriates and better economic opportunities in the city than are found in Sylhet's hinterland. These factors encourage people to live in the urban area with better services and various infrastructure facilities. Analysis of historical earthquake data shows that devastating earthquakes (with high magnitudes) in Bangladesh occurred mostly in the northeastern region and caused extensive

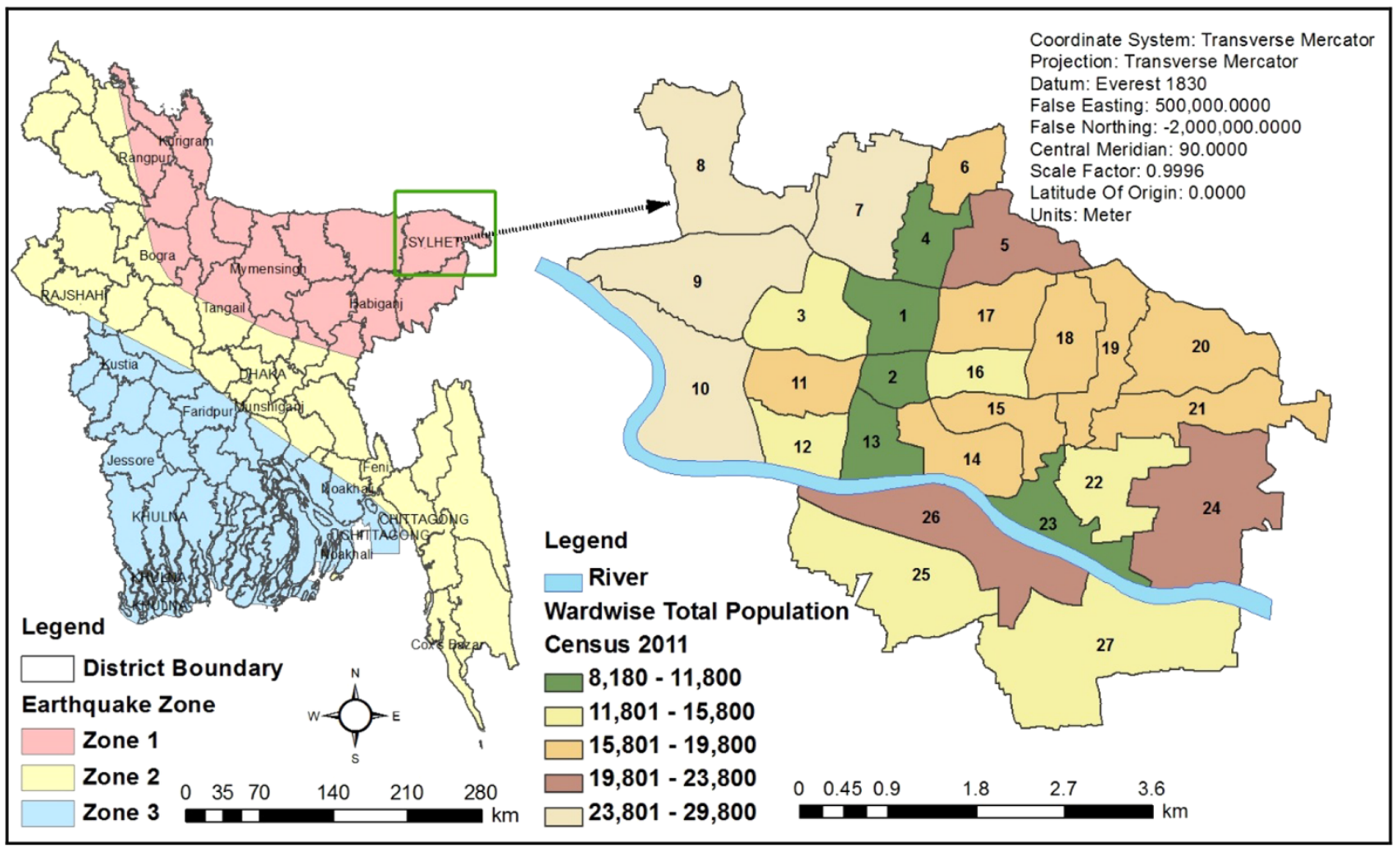

Fig. 1 The Earthquake-prone zones in Bangladesh (left) and Sylhet City with wardwise population (Right) 
Table 2 Main datasets used for population modeling and loss estimation

\begin{tabular}{lll}
\hline Dataset & Source & Data type \\
\hline Building inventory database (building use, area, structure type) & Secondary (CDMP study) & Vector data (polygon) \\
Occupancy specific average persons per $100 \mathrm{~m}^{2}$ & Secondary (CDMP study) & Table (text) \\
Earthquake ground motion (PGA and $S_{a}$ in $g$ ) & Secondary (CDMP study) & Report \\
Two specific occupancy class population distribution for 2 $\mathrm{h}$ interval & Primary (field survey) & Database (MS Excel) \\
\hline
\end{tabular}

$g$ is the measurement unit of spectral acceleration $\left(S_{a}\right)$ and PGA. $1 g=981 \mathrm{Gal}=9.81 \mathrm{~m} / \mathrm{s}^{2}$

damage in those areas with brick masonry buildings (Ansary and Sharfuddin 2000). Historical data analysis also suggests that this region might experience damaging earthquake with intensities up to IX MMI (Ansary 2002). Most of the buildings in Sylhet are constructed without engineering design and are highly vulnerable to moderate and severe earthquakes.

\section{Data and Methodology}

This section presents an overview on the main dataset used, their sources, types and the steps to process the data for the analysis.

\subsection{Datasets}

This study is mainly based on the datasets from the Comprehensive Disaster Management Program (CDMP) study in Bangladesh in 2009. Some of these datasets are in the vector format of ArcGIS and others exist in text format or as reports. The most crucial part of the datasets is the average number of persons per $100 \mathrm{~m}^{2}$ found in 27 different occupancy classes. Density per $100 \mathrm{~m}^{2}$ is a critical variable used to calculate the total number of people living in a building type throughout the whole city except for mixed-use buildings and schools. This dataset is also used to produce population distribution maps at the building level. For loss estimation, the earthquake hazard information in ground motion, which is measured in Peak Ground Acceleration (PGA) and Spectral Acceleration $\left(S_{a}\right)$, are also taken from the CDMP's hazard map. Besides these secondary sources, population distribution data at $2 \mathrm{~h}$ intervals in a day are collected in two types of buildingsmixed-use buildings and schools-through field survey. Table 2 describes the datasets used, their sources, and their data format.

\subsection{Methodology}

As existing population data have a very large uncertainty element for mixed-use and school buildings, a $2 \mathrm{~h}$ interval is employed to obtain precise information about the level of population presence in those buildings. The method anticipates that great variation in the occupancy of mixeduse buildings exists throughout the day and high concentrations of people in the schools only occur in specific hours of a day. In the context of Bangladesh, mixed-use buildings are buildings that have a combination of more than one occupancy class, such as residential and commercial, residential and office, light industry, and so on.

This article focuses on the effect of population changes in four different temporal cycles (weekday, weekly holiday, strike day, and Ramadan) to understand the major variations in population distribution over the course of a year. In Bangladesh, Sunday to Thursday are considered as weekdays and most of the people usually start for their destination (school, work, and so on) from 8 a.m. on those workdays. The weekly holidays are Friday and Saturday. Government offices and educational institutions are mainly closed during these 2 days, while local shops and some markets remain open. Strike events are very common in Bangladesh due to an unstable political climate. Planned strikes and protest activities occur between dawn and dusk in a particular day designated by a political party as a day for demonstrations. On average, the number of strike days varies from 20 to 30 days in a year. UNDP-Bangladesh (2005) describes in detail the strike scenarios in Bangladesh, and mentions that strikes have strong negative impact on society. For example, strikes disrupt the mobility of people, hamper business activities, and interfere with travel to work, as well as potentially cause the loss of a paycheck, and so on. The other temporal cycle, Ramadan, is a period of 30 days each year when Muslims fast between dawn and dusk. In recognition of the strain this abstinence places on strict participants in Ramadan, office hours usually start later in the morning and end earlier in the afternoon than the rest of the year. In most cases, the government declares a vacation in the educational institutions at all levels during this period.

Besides religious observances, such as Eid al-Fitr (religious festive day at the end of Ramadan) and Eid al-Adha (a 3 day major Islamic holiday later in the year), there are also other days, for example, the Bengali New Year day, which are national (or government) holidays. The national 
secular holiday scene is not considered specifically because most of these celebrations fall on the same days (Friday and Saturday) as the weekly holiday. In both the Bengali New Year and the Eid festivities buildings are occupied by few people. Specific analysis is limited to the four temporal scenarios that impact the large-scale movement and timing of activities in and around buildings and it is anticipated that these scenarios might show a large variation in population distribution over a day. To complete the questionnaire survey, a stratified random sampling technique was used to select the population samples from mixed-use buildings and schools. From each of the occupancy classes $5 \%$ samples were taken. The sample size was determined based on the number of buildings in the study area, which was established by consulting the existing CDMP building database. Most of the mixed-use buildings are located in wards 11-16. Finally a total of 48 mixed-use buildings (120 households) and 20 schools (scattered throughout the wards) were surveyed. After the data collection, processing and modeling of spatiotemporal and other spatial data were conducted in MS Access, MS Excel, and a Geographic Information System (GIS). GIS offers easy access to spatially arranged data and a range of tools with which to edit, update, and analyze these data. GIS is mainly used for population distribution modeling, analysis, mapping, and illustrating the results. Figure 2 shows the schematic workflow of the process to calculate the potential population loss.

\subsubsection{Population Distribution and Modeling}

In the CDMP (2009) study, the number of people in each occupancy class is calculated using an average number of people on each floor area multiplied by the floor space of the building. This is an approximation method developed by the Applied Technology Council (1985). It further helps to calculate the population in a building and population distribution modeling.
Fig. 2 Flowchart showing major steps to calculate the potential population loss

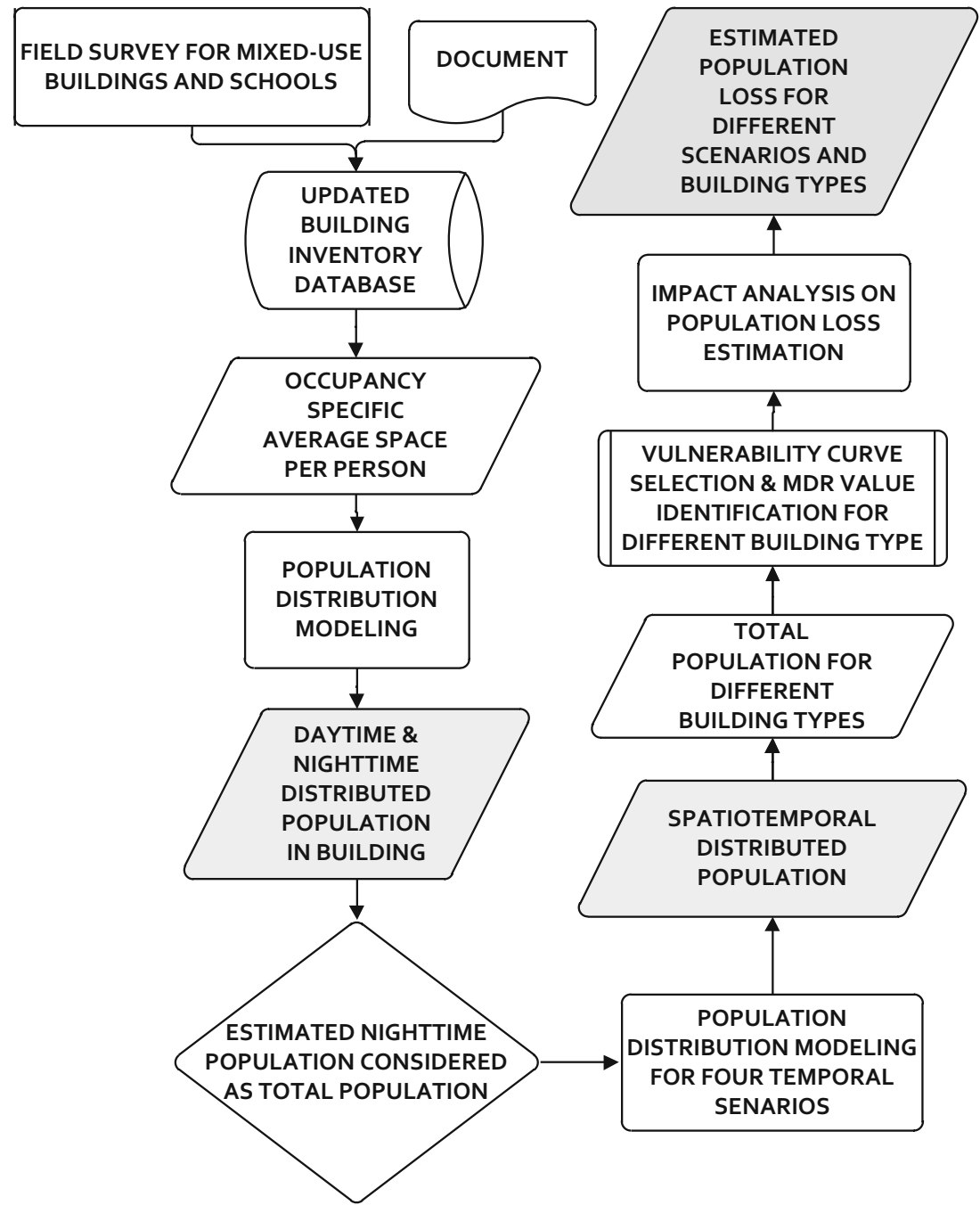


4.2.1.1 Floor Space and Population Calculation Since mixed-use buildings and schools are surveyed only in this study, the average population calculation for these two types is described below:

Mixed-Use Buildings Only the surveyed floor of a building (because of the unavailability of the dwellers) is taken into account to calculate the persons per $100 \mathrm{~m}^{2}$ number. After the calculation of total floor space and the total population at $2 \mathrm{~h}$ time intervals, the number of persons per $100 \mathrm{~m}^{2}$ for each building was calculated using Eqs. (1) and (2). The time period is aggregated to two groups: daytime and nighttime. Daytime and nighttime are considered from 8 a.m. to 6 p.m. and 6 p.m. to 8 a.m. respectively according to the CDMP study (2009). The average number of persons per $100 \mathrm{~m}^{2}$ is calculated for daytime ( 8 a.m. -6 p.m.) and nighttime (6 p.m. -8 a.m.) by adding the average value for specific time periods and dividing by the number of time periods using Eqs. (3) and (4).

Weighted arithmetic mean for the number of persons in $2 \mathrm{~h}$ interval,

$\bar{X}=\frac{1}{N} \times \sum_{i=1}^{N} \frac{X_{i} \times A_{i}}{\bar{A}}$

Average number of persons per $100 \mathrm{~m}^{2}$ for $2 \mathrm{~h}$ interval,

$X_{a}=\frac{\bar{X}}{\bar{A}} \times 100$

Table 3 Main input data used for total population calculation

\begin{tabular}{|c|c|c|c|c|}
\hline \multirow[t]{2}{*}{ S. no. } & \multirow[t]{2}{*}{ Occupancy type } & \multirow[t]{2}{*}{ Occupancy class description } & \multicolumn{2}{|l|}{$\begin{array}{l}\text { Population per } 100 \mathrm{~m}^{2} \\
X \pm \sigma\end{array}$} \\
\hline & & & Daytime & Nighttime \\
\hline 1. & RES1 & Single family dwelling & 2.62 & 3.93 \\
\hline 2. & RES2A & Minimum standard housing ( $<25$ occupants) & $5.88 \pm 6.47$ & $10.26 \pm 11.57$ \\
\hline 3. & RES2B & Minimum standard housing (25-100 occupants) & $10.04 \pm 10.92$ & $22.90 \pm 23.06$ \\
\hline 4. & RES2C & Minimum standard housing ( $>100$ occupants) & $2.63 \pm 1.47$ & $4.02 \pm 2.92$ \\
\hline 5. & RES3A & Multi family dwelling ( $<10$ units) & $2.65 \pm 2.62$ & $4.37 \pm 3.59$ \\
\hline 6. & RES3B & Multi family dwelling (10-19 units) & $3.40 \pm 2.62$ & $5.61 \pm 3.59$ \\
\hline 7. & RES4 & Hotel/motel & $3.64 \pm 3.30$ & $6.13 \pm 5.82$ \\
\hline 8. & RES5 & Institutional dormitory & $3.59 \pm 4.18$ & $5.79 \pm 5.48$ \\
\hline 9. & RES6 & Substandard housing & $22.25 \pm 21.05$ & $45.13 \pm 35.75$ \\
\hline 10. & COM1 & Small shop and market & $7.18 \pm 7.11$ & $1.07 \pm 3.32$ \\
\hline 11. & COM2 & Large shop and market & $5.21 \pm 5.66$ & $0.64 \pm 1.07$ \\
\hline 12. & COM3 & Automobile workshop & $11.13 \pm 11.02$ & $1.71 \pm 1.76$ \\
\hline 13. & COM4 & Office (professional or technical service) & $5.02 \pm 5.43$ & $0.69 \pm 1.12$ \\
\hline 14. & COM5 & Bank & & \\
\hline 15. & COM6 & Hospital & $23.63 \pm 9.38$ & $20.53 \pm 6.94$ \\
\hline 16. & COM7 & Clinic/Doctor's chamber & $3.78 \pm 4.69$ & $1.83 \pm 0.69$ \\
\hline 17. & COM8 & Restaurant and entertainment & $43.01 \pm 27.56$ & $1.35 \pm 1.33$ \\
\hline 18. & COM9 & Theater/community center & $36.30 \pm 29.86$ & $3.02 \pm 4$ \\
\hline 19. & COM10 & Mixed-use (residential and commercial) & $\begin{array}{l}5.59 \pm 5.71 \\
\text { F.S.: } 4.15 \pm 0.83\end{array}$ & $\begin{array}{l}4.18 \pm 4.66 \\
\text { F.S.: } 3.14 \pm 1.25\end{array}$ \\
\hline 20. & IND1 & Heavy (plastic, rubber, car) industry & $3.45 \pm 5.50$ & $2.53 \pm 5.03$ \\
\hline 21. & IND2 & Light (textile and garments factory) industry & & \\
\hline 22. & IND3 & Food/drug/chemical processing factory & & \\
\hline 23. & AGR1 & Farm house, poultry farm, dairy farm & $7.01 \pm 11.03$ & $0.13 \pm 0.21$ \\
\hline 24. & REL1 & Mosque/temple & $44.06 \pm 38.57$ & $1.12 \pm 6.87$ \\
\hline 25. & GOV1 & Government office, post office, telephone office, water pump house & $9.31 \pm 9.21$ & $3.60 \pm 4.67$ \\
\hline 26. & EDU1 & Primary school, high school, religious school & $\begin{array}{l}30.95 \pm 23.99 \\
\text { F.S.: } 58.74 \pm 35.20\end{array}$ & $\begin{array}{l}4.24 \pm 6.64 \\
\text { F.S.: } 0.31 \pm 1.02\end{array}$ \\
\hline 27. & EDU2 & College, university & $22.86 \pm 9.15$ & $0.02 \pm 0.02$ \\
\hline
\end{tabular}

F.S. field survey

Source CDMP (2009) and field survey in 2012 
Table 4 Factors affecting population distribution in a typical workday

\begin{tabular}{|c|c|}
\hline Occupancy type & Factors \\
\hline Residential & Working hour is from 9 a.m. to 5 p.m., people start going out at least from 8 a.m. \\
\hline \multirow[t]{2}{*}{ Commercial } & Market opening time is from 10 a.m. to 10 p.m. \\
\hline & $\begin{array}{l}\text { People's presence in markets gradually increases from } 12 \text { a.m. till } 10 \text { p.m., particularly from } 6 \text { p.m. to } 8 \text { p.m. Most } \\
\text { people come to the market for shopping after their office }\end{array}$ \\
\hline $\begin{array}{r}\text { Educational } \\
\text { institution }\end{array}$ & School hour is usually 10 a.m.-4 p.m. \\
\hline Religious place & $\begin{array}{l}\text { People usually gather in mosques or other religious places in the specific prayer time. For example, in the middle of the } \\
\text { day ( } 12 \text { a.m.- } 2 \text { p.m.) and in the evening ( } 4 \text { p.m. }-7 \text { p.m.), people come to mosque for prayer. Few people also go to the } \\
\text { mosque at dawn ( } 5 \text { a.m. }-6 \text { a.m.) }\end{array}$ \\
\hline $\begin{array}{l}\text { Restaurant/ } \\
\text { recreational }\end{array}$ & $\begin{array}{l}\text { Gradual increase of population in restaurants and recreational places. The percentage of people going to restaurants is } \\
\text { relatively small in the morning but it increases gradually in the afternoon (usually after } 12 \text { p.m. till } 4 \text { p.m.), mainly } \\
\text { because of lunch. In recreational places, people's presence is even less in the morning but it increases gradually }\end{array}$ \\
\hline Industry & Working hour for industrial workers also starts from 9 a.m. and most workers are present by that time \\
\hline $\begin{array}{l}\text { Hospital/Doctor's } \\
\text { chamber }\end{array}$ & $\begin{array}{l}\text { Generally people come to visit a doctor in the evening. So people's presence in doctor's chamber is relatively less in } \\
\text { daytime than nighttime but in hospitals it remains the same most of the time }\end{array}$ \\
\hline
\end{tabular}

Daytime average persons per $100 \mathrm{~m}^{2}$

$\frac{\sum_{i=1}^{5} X_{a i}}{\sum_{i=1}^{5} \text { no. of time periods }}$

Nighttime average persons per $100 \mathrm{~m}^{2}$

$\frac{\sum_{i=1}^{7} X_{a i}}{\sum_{i=1}^{7} \text { no. of time periods }}$

Schools For schools, the time-based population distribution is divided into two groups: school hours and nonschool hours. Most of the schools in Sylhet City begins at 10 a.m. and ends at 4 p.m. The school hour is considered to be daytime (from 8 a.m. to 6 p.m.) and the rest of the time is considered nighttime.

Daytime average persons per $100 \mathrm{~m}^{2}$

$\frac{1}{N} \times \sum_{i=1}^{20}\left(\frac{X_{i \text { day }}}{A_{i}}\right) \times 100$

Nighttime average persons per $100 \mathrm{~m}^{2}$

$\frac{1}{N} \times \sum_{i=1}^{20}\left(\frac{X_{\text {inight }}}{A_{i}}\right) \times 100$,

where $\bar{X}$ is the weighted arithmetic mean, $X_{i}$ is the number of people per use area of building $i, X_{i \text { day }}$ is the number of people in the school in daytime, $X_{i n i g h t}$ is the number of people in the school in nighttime, $X_{a i}$ is the persons per $100 \mathrm{~m}^{2}$ in building $i, A_{i}$ is the used area of the building $i\left(\right.$ in $\left.^{2}\right), \bar{A}=\frac{1}{N} \sum_{i=1}^{N} A_{i}$, $N$ is the number of sampled schools/buildings.

The above calculation provides the result of average space per person for mixed-use buildings and schools, which is used along with Table 3 for the remaining 25 occupancy classes to estimate the daytime and nighttime population. Here a statistical modeling approach (developed in the CDMP 2009 study, see Table 1) is adopted to distribute the population in the buildings, which establishes a correlation between population density and occupancy classes.

4.2.1.2 Modeling of Population Distribution The estimated daytime and nighttime populations are considered as a normal workday population and the nighttime population is considered as the city's total population. Based on this assumption, population is distributed in the different occupancy classes of the whole city. This procedure only considers the people who are inside a building at a certain point in time, because the available dataset does not describe how many people are outside the building and/or are coming to or leaving the city.

For the four different scenarios, presence (in percentage) of the people in the building at every $2 \mathrm{~h}$ interval is approximated based on expert judgment and field survey experience. Some practical factors that might affect people's presence over the time periods of the day are also considered. Because of these factors, the presence of the people varies from one occupancy class to another and as a result the weighting varies. Table 4 illustrates the possible factors for a typical weekday and the other three temporal scenarios are considered similarly. Ara (2013) described in detail how these factors were developed. Different building types influence the number of people present at different times. Specific sociopolitical factors also play a major role. For example, in residential buildings $80 \%$ of the nighttime population remains at home from 8 a.m. to 10 a.m. The percentage of stay-at-home population tends to decrease until 2 p.m. at which time the percentage of population present at home starts to increase. Also only about $75-90 \%$ of nighttime populations remain at home during 


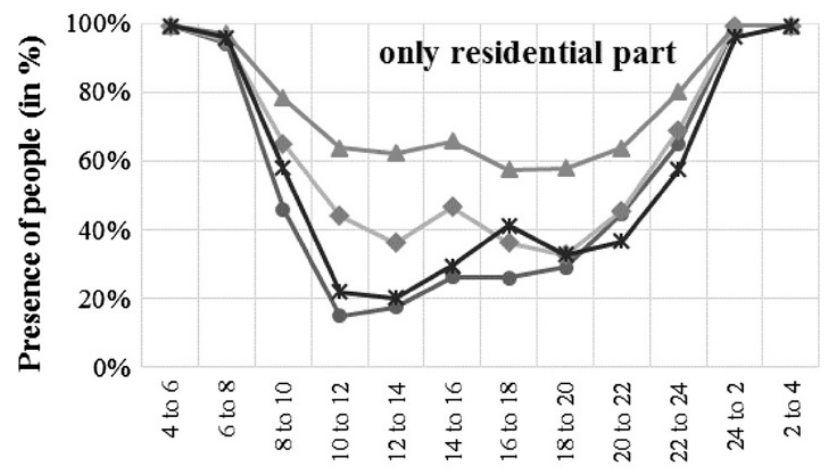

Time period (in hour)

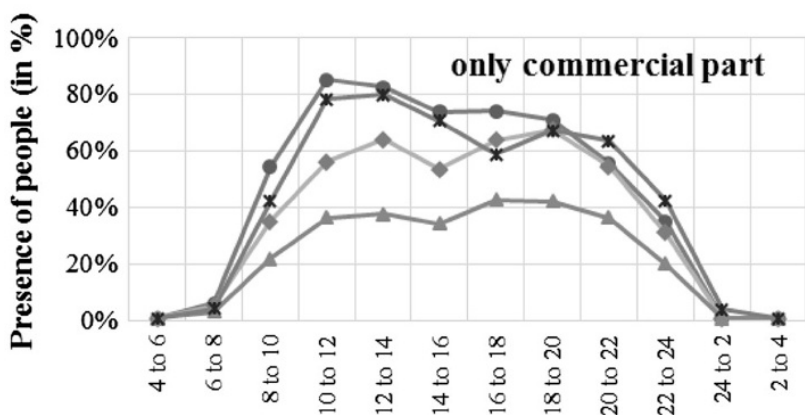

Time period (in hour)

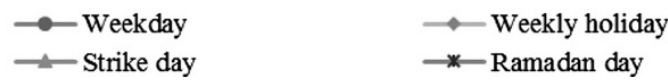

Fig. 3 Presence of the people in mixed use buildings (surveyed): showing the fluctuations in residential and commercial part during different time period of the day for four temporal scenarios

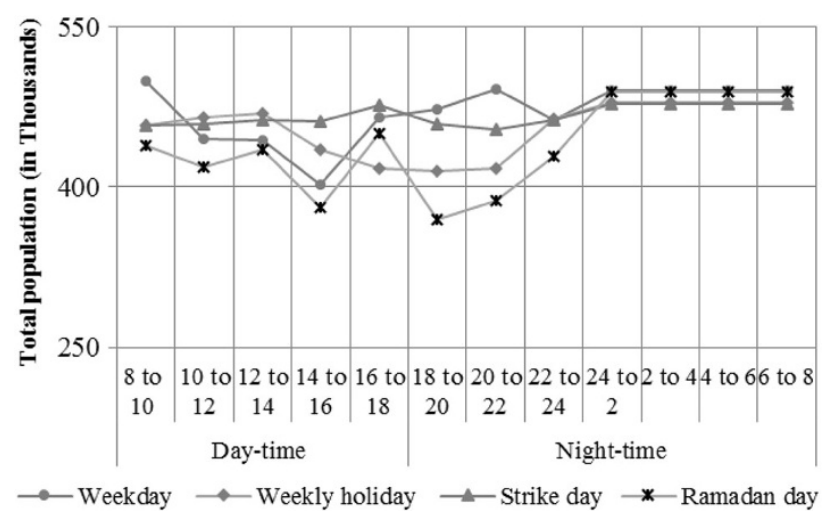

Fig. 4 Total population distribution in buildings over different time periods of the day in four temporal scenarios

the 8 p.m. -10 p.m. time block depending on the specific category of residential building in which they live. Similar observations can be made about the different occupancy rhythms followed among residents of different classes, traditions, and neighborhoods. This variable population distribution modeling keeps the total number of population (as estimated in Sect. 1) unchanged in nighttime.

\subsubsection{Impact of Population Distribution on Population Loss Estimation}

The result of the population distribution modeling is used to analyze the impact on population loss estimation that occurs at different time periods of the day and year. For this analysis the ERN-vulnerability curve module of CAPRA is used (CAPRA 2012). Specific human vulnerability curve for each available building structural type represents the damage potential of earthquake impact on the population expressed as a mean death ratio (MDR). The vulnerability curves exhibit a strong correlation between damage potentiality (in terms of casualties) and ground motion of earthquake. Potential loss of people increases due to high-intensity earthquake events. In the ERN-vulnerability curves the intensity level (measured by ground motion or acceleration) is required to identify the possible vulnerability of residents of specific building types. But the vulnerability situation is not universal; it varies from country to country due to different building structures. The vulnerability of people also significantly varies because of social characteristics, but this research did not considered specific social characteristics in detail. Instead it employed the vulnerability curves as a surrogate and used those curves for test purposes. This research used five different scenario earthquakes: Dauki Fault (DF) $\mathrm{Mw}$ 8.0, Plate Boundary Fault-2 (PBF-2) Mw 8.3, Mw 6.0 beneath the city, DF Mw 8.5, and DF Mw 8.0 with different ground motion levels. Among these five scenario earthquakes the last two are probabilistic earthquake cases. The probability of exceedance (PE) of these two probabilistic scenario earthquakes is $10 \% \mathrm{PE}$ in 50 years and $2 \% \mathrm{PE}$ in 50 years respectively. Several steps that are followed to calculate the potential losses of life are given below:

- The existing building types in this study area are adapted to the building types available in the ERNvulnerability curve module of CAPRA. For this, building types are combined based on the construction material and technique.

- There is no curve available for the building type "bamboo made house" in CAPRA. There is also no existing study of the vulnerability curve for this structural type available in Bangladesh. Thus its population (in daytime 23,610 and nighttime 34,912) is not included in the analysis.

- The population for each building type is calculated for the four different temporal scenarios.

- Five different scenario earthquakes and their minimum and maximum spectral acceleration $\left(S_{a}\right)(T=0.3 \mathrm{~s})$ are taken from the CDMP hazard intensity map. These values are used to calculate the minimum and maximum probable human losses. 
- For the minimum and maximum ground motion, the vulnerability value is identified from the vulnerability curve for each type of building.

- These minimum and maximum values are multiplied by the total number of people present in each type of building in different $2 \mathrm{~h}$ time blocks of the day. This calculated loss of life indicates only the general possible loss because of the different structural categories and earthquake intensities.

\section{Results}

This section presents the results of the analysis by describing how the population varies in different occupancy classes, different time periods of four temporal scenarios as well as how these variation of population influences the loss estimation for different earthquake scenarios. A comparative analysis is also carried out based on the analysis.

\subsection{Presence of Population in Buildings}

Weekday Mixed-use buildings attract people from different locations who come to the shops/markets and offices to work and do shopping, usually linked to the workday beginning by 8 a.m. Usually most of the people who come to the city during working hours in the daytime leave at night (mainly after 8 p.m.). Generally housewives, old family members (or inactive people), unemployed persons, and children (younger than 5 years) remain at home most of the time. In schools, on average, $80 \%$ of the students and $100 \%$ of the staff (including teachers) are present during school hours.

Strike Day Sylhet is a relatively small city and most of the offices and markets are located in Zindabazar, the center of the city. If a strike is declared by any political party, almost all the shops, markets, and educational institutions remain closed. Consequently there are markedly fewer people present in the city center. Generally government officials and school teachers come to work on a strike day.

Ramadan Days During the month of Ramadan, office hours are relatively shorter than usual, most businesses not opening before 10 a.m. and most closing by 3 p.m. However the markets remain open till late at night (12 p.m. or later). In contrast, almost all educational institutions shut down from the start of Ramadan and the remaining schools close between the 15 th to the 20th days of Ramadan. Therefore, the presence of people decreases in the educational institutions throughout Ramadan and increases in the markets and shops.
Weekly Holiday On the weekly holiday, especially on Friday, the local shops and a few markets are open between 2 p.m. and 4 p.m. But most of the educational institutions, some private offices, and many markets and shops remain open on Saturday. On Friday there is a special prayer for male Muslims from 12 a.m. to 2 p.m., so at this time most men go to the mosques. Some people go out with their family in the evening to their relatives' homes. In the weekend holidays most of the marriage ceremonies, anniversaries, and birthdays are celebrated and most social gatherings occur.

These four temporal scenarios show variations in the persons per $100 \mathrm{~m}^{2}$ density figure for daytime and nighttime. Figure 3 illustrates the fluctuations of population distribution in the mixed-use buildings in four temporal scenarios for different times of the day. The estimated population of Sylhet in daytime is 546,700 and nighttime is 490,370. As described in Sect. 4.2.1.1, this nighttime population is considered as the city's total population.

\subsection{Population Distribution Modeling}

The output of the population distribution modeling is represented in Fig. 4. It shows the fluctuations of the

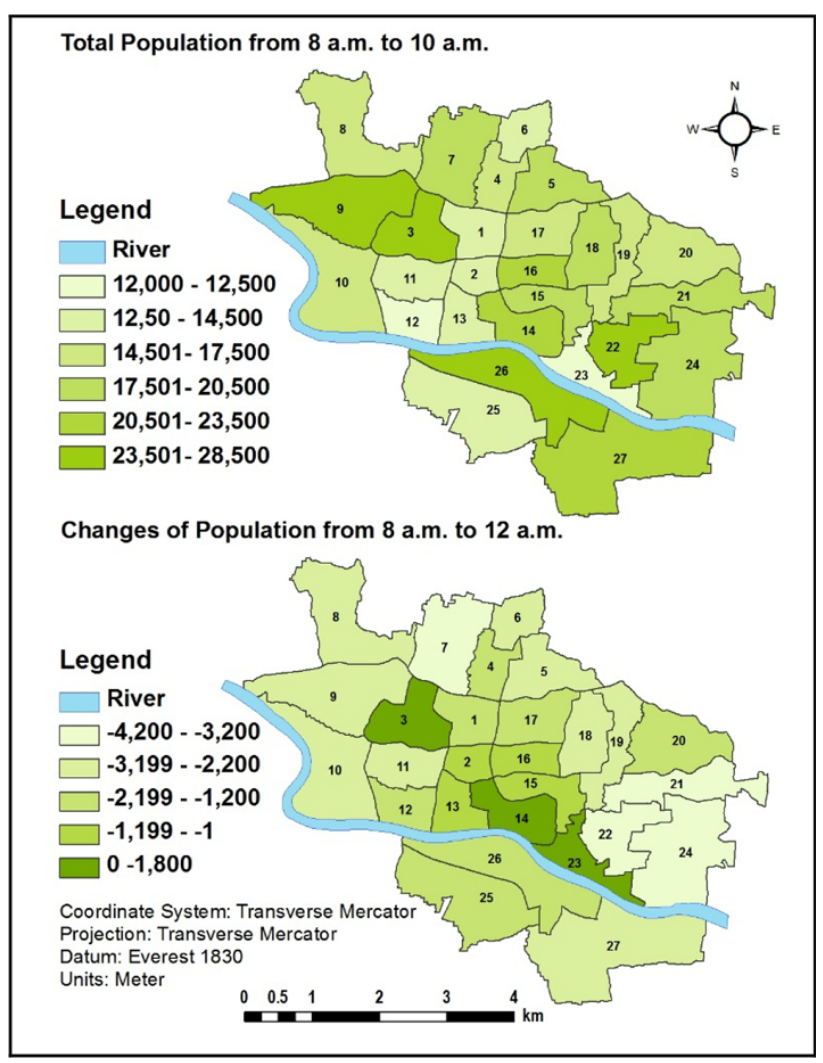

Fig. 5 Population distribution in a typical weekday from 8 a.m. to 10 a.m. (top) and difference from 8 a.m. to 12 a.m. (bottom) in the study area at the ward level 
population inside the buildings in different time periods and compares the overall scenarios of distribution. Based on the result all the temporal scenarios are discussed below.

Weekday Scenario In 2013, the number of workdays was 191 (excluding Friday, Saturday, Ramadan days, and government holidays) in Bangladesh, which is applicable to government offices and banks. Therefore the chance of occurrence of an earthquake event in weekdays is $30 \%$ at night and $22 \%$ at daytime. There are different factors that might affect the distribution of the people in a building based on their occupancy classes. Among them the most influential factors are working hours in the office and industry (9 a.m.-5 p.m.), market opening times, school hours, prayer times, social activity, and so on. By considering these factors, the population is distributed among the buildings. Figure 5 illustrates the population distribution scenario of the study area from 8 a.m. to 10 a.m. and the difference in the population from 8 a.m. to 12 a.m. This figure aggregates the population in the buildings to the ward level. The negative value indicates that the population has decreased from those wards from 8 a.m. to 10 a.m. Wards $3,7,9,22$, and 26 show a decrease of population from the morning, because these areas are mainly residential. On the other hand the population density increases in the commercial area, for example, in wards $12,13,14$,
Fig. 6 Changes of population in a strike day at the ward level in different time periods from 8 a.m. to 8 p.m.

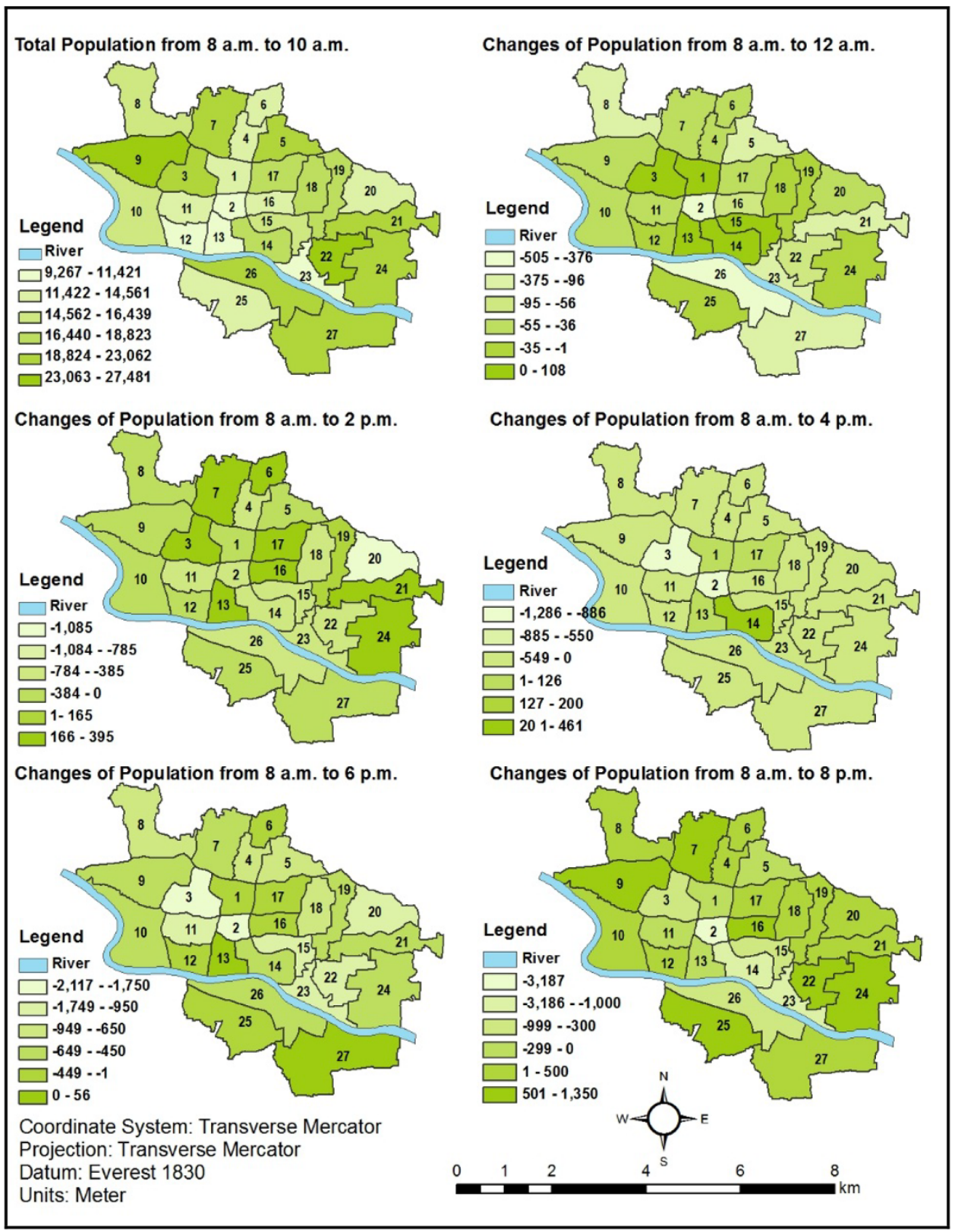


and 25 . In this study area, mixed-use buildings are mostly located in specific areas and along the roads. Therefore the population density remains high in a few wards from 4 p.m. to 8 p.m. Typically most of the people are present at home after 10 p.m., but a certain amount of people who work in the markets stay out later in the evening. After 12 p.m. almost all the residents are inside their residential buildings.

Strike Day Scenario Strikes disrupt the efforts of people to carry out their normal workday activities, because mobility becomes difficult and physical security sometimes decreases. In such cases, strikes result in fewer citizens reaching their workplaces, attending markets, or visiting shops. Because most mosques and religious places are located in residential neighborhoods they are largely unaffected by strikes, since people can walk easily to prayer time and educational activities. In a normal workday, the total number of people present in some commercial buildings can reach as high as 1,000 . But in a strike day this number is comparatively very low (no more than 40). Figure 6 shows the temporal variations (from 8 a.m. to 8 p.m.) in the buildings that are aggregated by wards for a typical strike day.

Ramadan Day Scenario The daily population distribution during the month of Ramadan varies significantly in buildings of different occupancy types. The probability of occurrence of an earthquake event in these days at daytime and nighttime is lower than other scenarios. In Sylhet, about $87 \%$ of the population are Muslims (BBS 2011) and this has a significant influence on the population distribution during Ramadan. There are several causes behind the unique distribution during this time period, including the change of office time (10 a.m.-3 p.m.), expanded shopping for evening meals and festivities, student vacations from educational institutions, increased attendance at prayer times, and the greater presence of people in the mosque throughout the day.

In Ramadan the population density is high during daytime in the shopping centers and roadside shops because social activities and extended family meals after sunset brings an end to fasting as does the religious festival (Eid) at the end of the holy month. This creates more exaggerated swings in population distribution between markets and residential areas. But in the other commercial use buildings (for example, banks and offices) people start to leave the place after the office hour, and therefore population density becomes low in commercial districts. Figure 7 represents how the population changes over two time periods in one part of the city.

Weekly Holiday Scenario There are 124 weekly holidays, and 24 other government holidays in Bangladesh. In most cases the government holiday and weekly holiday scenarios are similar. In the weekly holidays, the probability of earthquake occurrence is $20 \%$ in nighttime and
Fig. 7 Daytime and nighttime scenarios in one part of the study area during Ramadan days

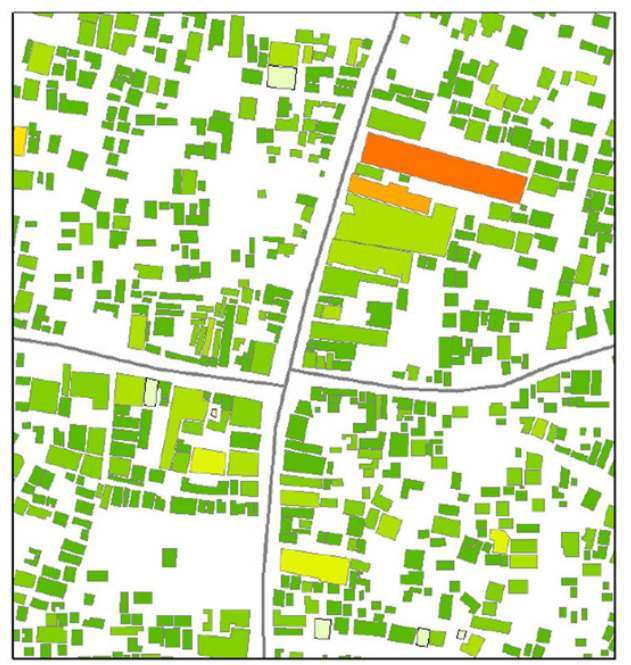

Legend

- Road

Population from 8 a.m. to 10 a.m.

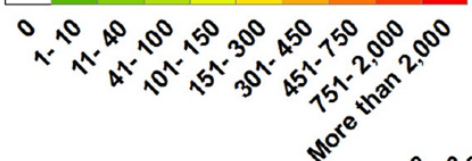

$0 \quad 0.040 .08$

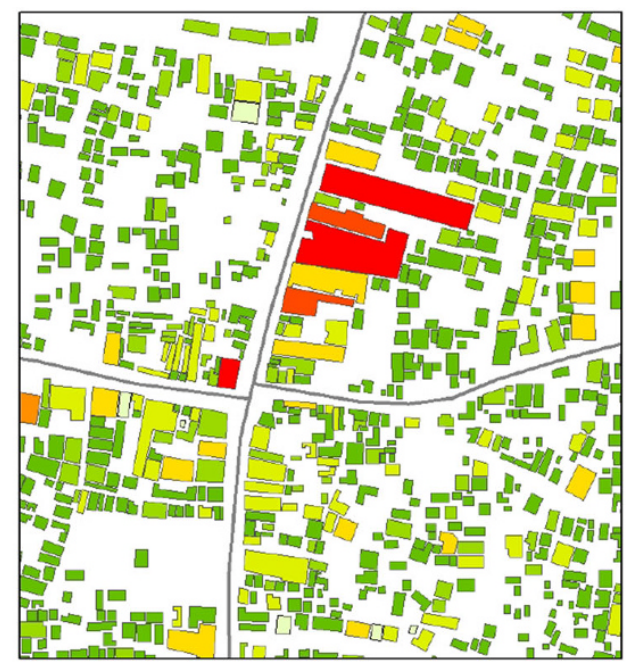

Legend

Road

Population from 6 p.m. to 8 p.m.
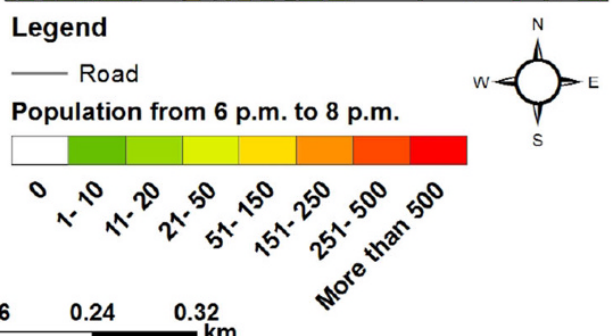
$14 \%$ in daytime. The spatial distribution of population in different building occupancy classes varies from the weekdays. The key factors that influence the variations in the spatiotemporal distribution of population are the number of social gatherings, Friday prayer, the increased
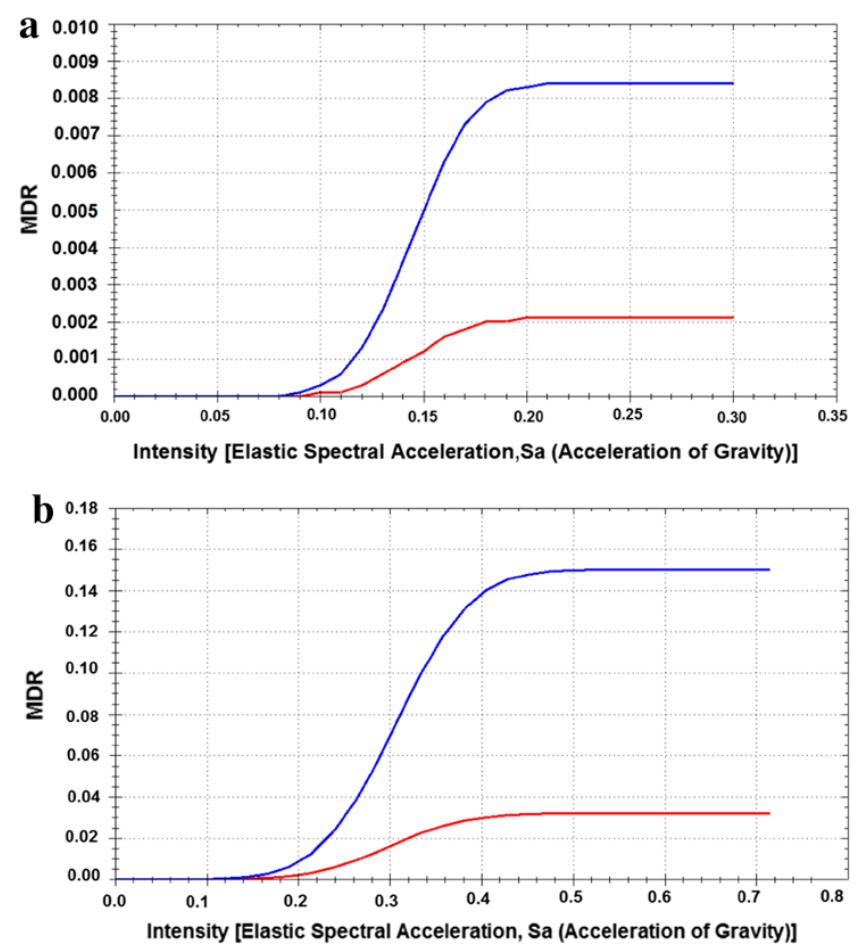

presence of the people in the city's recreational centers, and holiday closures in educational institutions and offices.

In the weekdays from 2 p.m. to 4 p.m. and in Ramadan days from 6 p.m. to 8 p.m. people are least likely to be present in either commercial or residential buildings. That
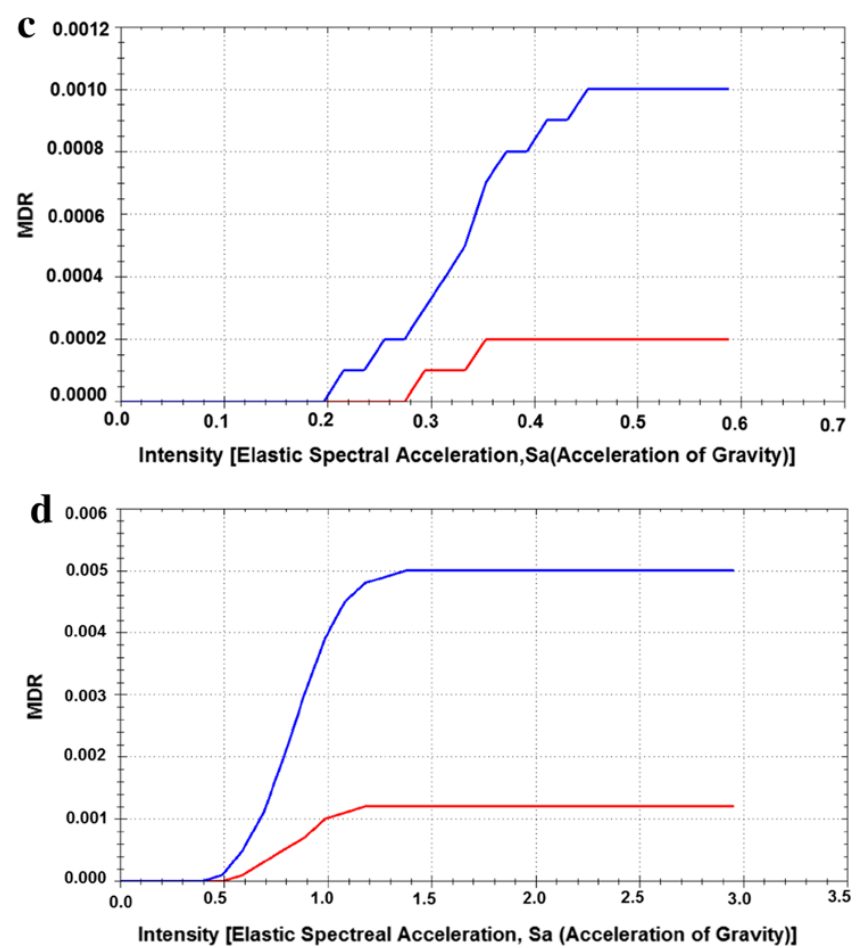

Fig. 8 Human vulnerability curves: a M34M building; b RC1L building; c S3L building; d WL building

Fig. 9 Comparison of minimum and maximum losses among the different earthquake scenarios in a weekday

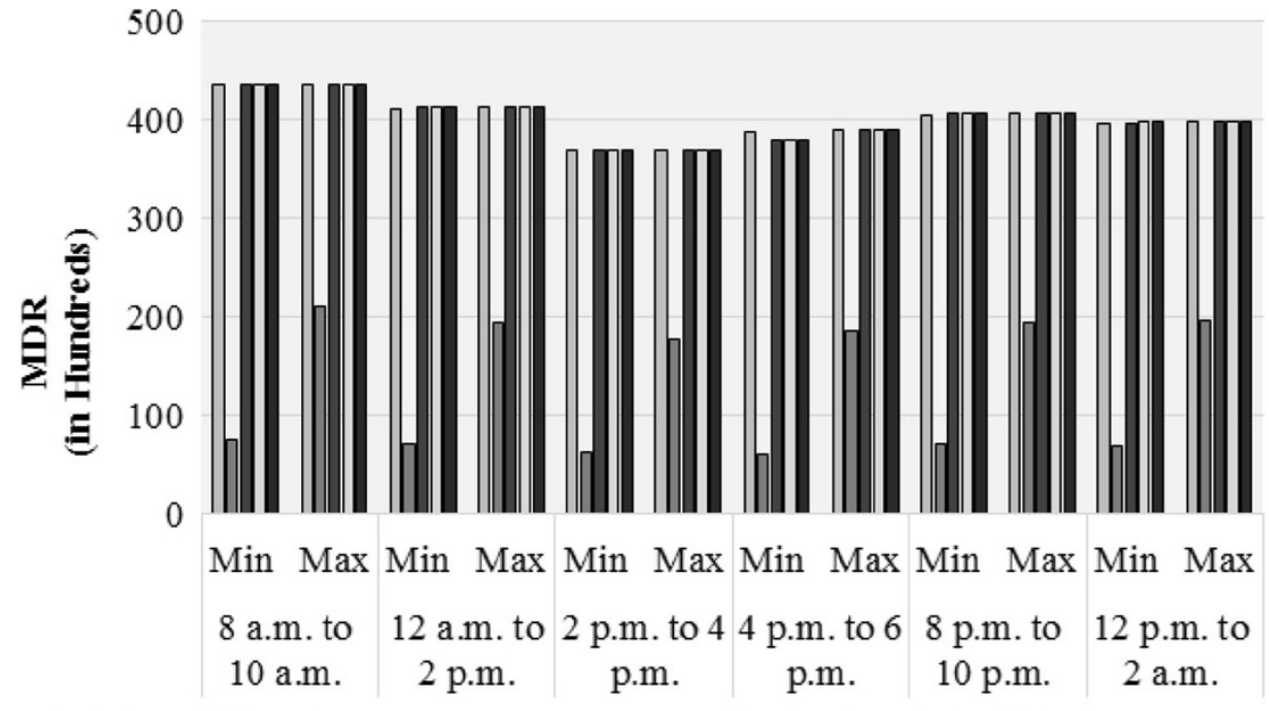

口Dauki Fault Mw 8.0

口Plate Boundary F ault-3 Mw 8.3

$\square \mathrm{Mw} 6.0$ beneath city

$\square$ Dauki Fault Mw 8.0 (10\% PE in 50 years)

Dauki Fault Mw 8.5 (2\% PE in 50 years) 
Fig. 10 Comparison of the four temporal scenarios in different time periods of the day

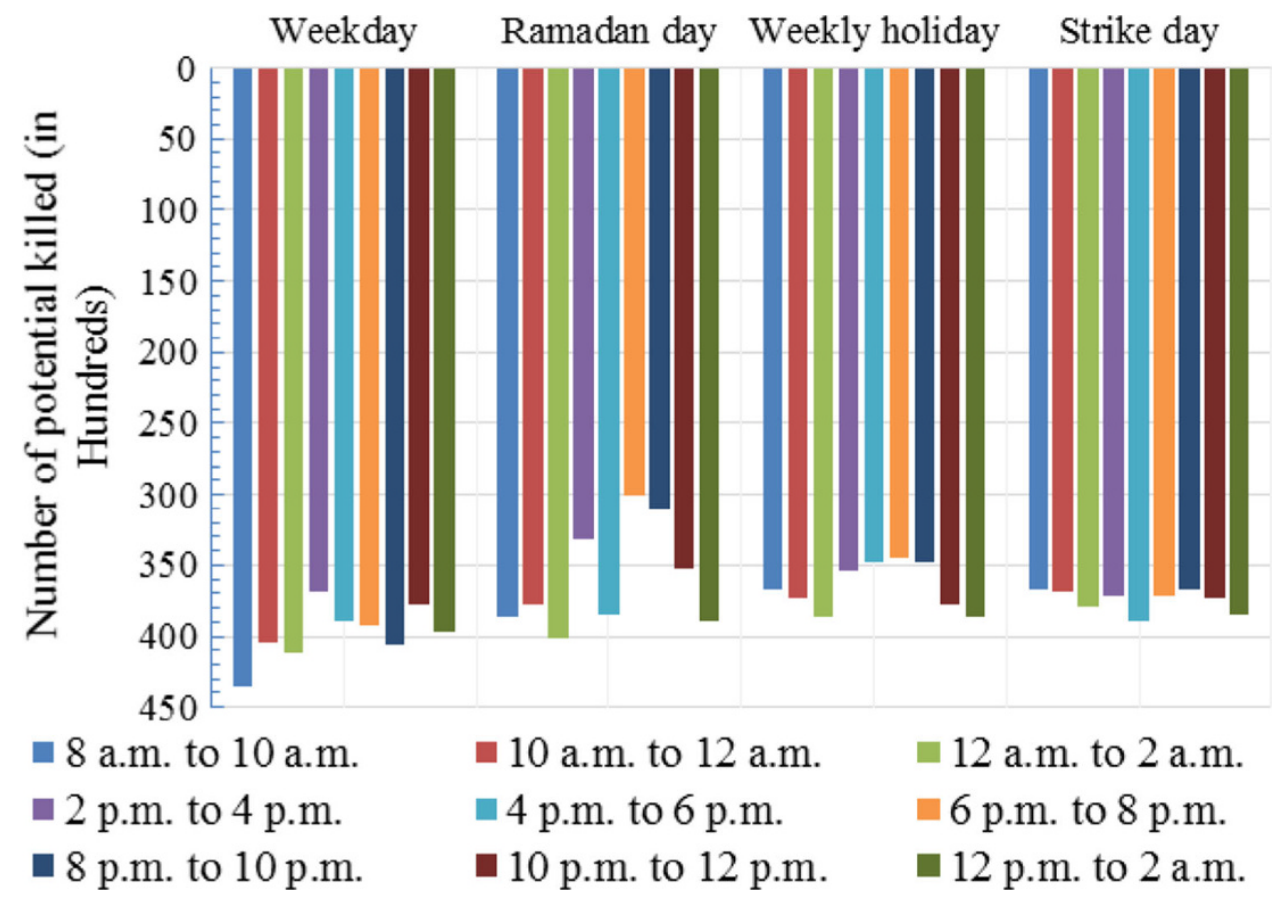

means in these periods most people are in the street or outside the buildings. In Ramadan more than $20 \%$ of the population may be out-of-doors in the evening. During weekly holidays and on strike days this average percentage falls to about 3-8\%. In weekday afternoons about $18 \%$ of the populace are outside buildings.

\subsection{Impact of Population Distribution on Loss Estimation Using CAPRA Vulnerability Curves}

Different population distribution scenarios are used to analyze how population loss estimations vary for different earthquake scenarios. For this analysis the modeled population distribution data and the minimum and maximum value of spectral acceleration are used. The human vulnerability values (specifically MDR) for different building types such as unreinforced masonry buildings (M34L and $\mathrm{M} 34 \mathrm{M})$, reinforced concrete buildings (RC1L, RC1M, and $\mathrm{RC} 1 \mathrm{H}$ ), steel (S3L), and wooden buildings (WL) are obtained from the CAPRA software where the last alphabet $\mathrm{L}, \mathrm{M}$, and $\mathrm{H}$ indicates the height of the building (low, medium, and high respectively). In these curves uncertainty is also considered (red lines) (Fig. 8).

\subsubsection{Comparison Among the Earthquake Scenarios}

The loss estimation analysis shows that there are differences in the number of potential population losses in different temporal scenarios of a year. The loss is enormous for four earthquake scenarios. But the Plate Boundary
Fault-3 with Mw $8.3\left(S_{a}=0.26-0.44 \mathrm{~g}\right)$ scenario shows the lowest population loss compared to the other four earthquake scenarios because the fault source for the quake is so far away from Sylhet.

Figure 9 shows that the maximum and minimum mean death is equal for nearly all other four earthquake scenarios because in the CAPRA vulnerability curves after a certain ground motion value the MDR remains constant (Fig. 8). In most of the earthquake scenarios the minimum and maximum values are very close to each other, therefore the MDR values are also the same.

\subsubsection{Comparison Among Temporal Scenarios in a Year}

In different temporal scenarios of the year, the weekday scenario experiences the worst losses. In this scenario the worst time period is from 8 a.m. to 10 a.m. in the morning, where the casualty is more than 43,000 (Fig. 10). However the Ramadan scenario and the weekly holiday scenario show their highest casualties in the middle of the day rather than in other periods. The morning of weekly holidays (8 a.m.-10 a.m.) shows the lowest potential casualty impact compared to other times. One of the main reasons is that the total population in the city is lower in early morning than at other times of the day. Among all the temporal scenarios daytime experiences the lowest loss level during the weekly holidays, but at nighttime (12 p.m.-2 a.m.) the lowest losses of life are encountered on strike days. 


\subsubsection{Comparison Among the Building Types}

The analysis found that the density of people is higher in reinforced buildings and brick masonry buildings than in any other building type. More specifically, in daytime, $76 \%$ of the population are inside low-rise reinforced buildings and low rise brick masonry buildings. Nevertheless, people inside reinforced concrete buildings are more vulnerable to earthquake because a high percentage are trapped beneath partly or totally collapsed structures. As a result, this type of building contributes $60 \%$ of the total loss sustained during an earthquake. WL and steel structures do not result in as many casualties as the other building types. But if any high rise and earthquake nonresistant buildings are located beside these buildings, people certainly would be affected. It is apparent from the analysis that differences in time of the day in which an earthquake strikes considerably varies the loss experienced. Loss levels depend on the number of people in buildings and what type of building people occupy in a specific period.

\section{Discussion}

There is a strong positive relationship between the spatiotemporal distribution of people and the potential number of casualties. The distribution of the people varies from daytime to nighttime among different occupancy classes and temporal scenarios in a year. The variation is particularly remarkable for commercial buildings. In residential buildings at least two persons are present during daytime while other residents go to schools, colleges, or work places. Each of the scenarios shows a distinct population distribution throughout the year. The strike day and Ramadan day scenarios show a different distribution than the weekday scenario even if these scenarios cover the weekdays of the year. In a strike day, population distribution fluctuates more in educational institutions than in other occupancy classes. As a consequence more people are found in residential buildings during strikes. Distribution of people also decreases in mixed-use buildings, markets, banks, and other commercial buildings because people do not go there during a strike except in an emergency. During Ramadan, the daytime population density increases mainly in the commercial buildings such as markets, shops (especially those dealing with clothing and fabrics), tailoring enterprises and so on). Ramadan decreases daytime customers in food shops, restaurants, and nonreligious recreational centers during daytime. The number of people also increases along the street in Ramadan due to the temporary markets that appear in the roadside footpath. There is a change in the work hours of offices and banks, so the amount of people in commercial districts and buildings varies from the levels normally encountered on regular workdays.

The analysis shows that different temporal scenarios in a year have different losses of life in the same $2 \mathrm{~h}$ period. The loss is $15 \%$ less on both strike days and weekly holidays and $11 \%$ less during a Ramadan day compared favorably to the typical weekday morning scenario. The study result indicates that in some specific time periods the amount of people in the street or outside the buildings increases. Another important factor affecting the large amount of people in the street is the open market (market in the footpath). In the Ramadan day and weekday scenarios about $20 \%$ of the people remains outside the buildings for some specific period of the day and in the strike day and weekly holiday fewer people are outside.

Vulnerability plays an important role in loss estimation. In the case of Bangladesh, a building-specific vulnerability curve has yet to be developed. Therefore CAPRA vulnerability curves were used. But the exact building types are often not found in CAPRA and even within a given building type vulnerability varies. There are also other parameters related to vulnerability, where any change in these parameters produces different mean death values. The CAPRA curves are dubious and there is no reference literature or explanation available for the given curves and building types.

\section{Conclusion}

This study develops an approach to distribute the population at the building level using the average occupancy based on building use. The primary weights assume a uniform distribution for each building regardless of its spatial location. This building level approach is different from other dasymetric population models for which the output results are mainly gridded or in raster format. The disaster impact of a strong earthquake in an urban area can be reduced by knowing the accurate and dynamic distribution of the city's people. Such knowledge also supports effective earthquake mitigation and response efforts. These spatiotemporal modelling data can be a significant input for risk assessment in high density urban areas such as Sylhet City. But there are some limitations to this modeling approach. Since the average occupancy is represented by a fraction of the population with uncertainty, the distributed population requires some adjustment technique to convert into integer numbers, which is not done in this calculation process. Also the population calculation does not consider the uncertainty of the input data, which change the number of people in daytime and nighttime in certain types of buildings. Therefore further investigation is recommended 
to clarify how these uncertainties in population distribution may affect the loss of life estimation in the context of risk assessment and decision making.

This study does not take into account how many people come to or go out of the city from districts outside the municipal boundary on a daily or seasonal basis. However it is assumed that in daytime fewer people go out and more people come into the city. Incorporating the commuting characteristics can improve this model significantly and can help to better assess the earthquake risk among a transient daytime population. People are always moving from one place to another using the streets, but data are not officially collected on the population components of these movements. Since Sylhet is densely populated and streets are narrow, this movement also creates high traffic congestion and delays. This factor is also not considered in the present study.

Population loss estimations are affected by population distribution (spatial and temporal) in different buildings, earthquake intensity, and the occupant trap percentage of different building types. Losses may vary depending on the earthquake's location in relation to residential areas, resident's social characteristics, and so on. There are several uncertainties in the given dataset (population distribution data, vulnerability function, ground motion) and methodology. To improve the results of such earthquake loss estimation studies, uncertainty needs to be tackled and reduced in the future to enhance acceptability and reliability of loss assessments. Future work also should focus on incorporating a greater and more systematic consideration of social characteristics with the population distribution and building characteristics of this project in order to achieve a better approximation of human losses in an earthquake.

Acknowledgments This article is part of the Master's thesis of the author, which was supported by a grant from the Netherlands Organization for International Cooperation in Higher Education (NUFFIC). The author would like to thank Dr. C. J. van Westen and Mr. B. G. C. M. Krol (ITC, University of Twente) for their consistent and kind support during the research period. Deep gratitude also goes to Ying Li, Editorial Director and the three anonymous reviewers for their insightful comments and feedbacks, which extensively improved this article. The author would like to give special thanks to Rifat Shams for her kind cooperation.

Open Access This article is distributed under the terms of the Creative Commons Attribution License which permits any use, distribution, and reproduction in any medium, provided the original author(s) and the source are credited.

\section{References}

Agrawal, S.K., and C. Ajay. 2004. Estimation of seismic vulnerability of buildings in Delhi. In World Congress on Natural Disaster Mitigations, 12. New Delhi: Building Materials and Technology Promotion Council (BMTPC).
Alexander, D. 1996. The health effects of earthquakes in the mid1990s. Disasters 20(3): 231-247.

Ansary, M.A. 2002. Earthquake damage scenario for Sylhet, Bangladesh. In Seventh U.S. National Conference on Earthquake Engineering. Boston, Massachusetts, USA.

Ansary, M.A., and M.R. Islam. 2008. Seismic microzonation of Sylhet City. Journal of South Asia Disaster Studies 1(1): 179-195.

Ansary, M.A., and M. Sharfuddin. 2000. Earthquake hazard scenario in greater Sylhet region. Paper presented at village infrastructure to cope with the environment conference, November 2000, Dhaka, Bangladesh.

Applied Technology Council. 1985. Earthquake damage data for California (ATC-13). California: Readwood City.

Ara, S. 2013. Analyzing population distribution and its effect on earthquake loss estimation in Sylhet, Bangladesh. Applied Earth Science Faculty of Geoinformation Science and Earth Observation, University of Twente, Enschede, the Netherlands.

Aubrecht, C., S. Freire, C. Neuhold, A. Curtis, and K. Steinnocher. 2012. Introducing a temporal component in spatial vulnerability analysis. Disaster Advances 5(2): 48-53.

BBS (Bangladesh Bureau of Statistics). 2011. Bangladesh population and housing census 2011: Community report on Sylhet Zila. Sylhet: Ministry of Planning.

Becker, R.A., R. Caceres, K. Hanson, J.M. Loh, S. Urbanek, A. Varshavsky, and C. Volinsky. 2011. A tale of one city: Using cellular network data for urban planning. IEEE Pervasive Computing 10(4): 18-26.

Bhaduri, B., E. Bright, P. Coleman, and M.L. Urban. 2007. LandScan USA: A high-resolution geospatial and temporal modeling approach for population distribution and dynamics. GeoJournal 69(1): 103-117.

CAPRA (Central American Probabilistic Risk Assessment). 2012. The probabilistic risk assessment initiative. http://www.ecapra. org/about. Accessed 16 Nov 2014.

CDMP (Comprehensive Disaster Management Program). 2009. Report on earthquake vulnerability assessment of Dhaka, Chittagong and Sylhet City Corporation Area. Dhaka: Government of Bangladesh.

Chen, Q.F., Y. Chen, and L. Chen. 1997. Earthquake loss estimation by using gross domestic product and population data. Acta Seismologica Sinica 10(6): 791-800.

Chen, Y., G.P. Li, Q.F. Chen, L. Chen, and M.F. Li. 1998. Earthquake damage and loss estimation with geographic information system. Acta Seismologica Sinica 11(6): 751-758.

Chen, K.P., J. McAneney, R. Blong, R. Leigh, L. Hunter, and C. Magill. 2004. Defining area at risk and its effect in catastrophe loss estimation: A dasymetric mapping approach. Applied Geography 24(2): 97-117.

Chiroiu, L. 2005. Damage assessment of the 2003 Bam, Iran, earthquake using Ikonos imagery. Earthquake Spectra 21(S1): S219-S224.

Chiroiu, L., and G. André. 2001. Damage assessment using high resolution satellite imagery: Application to 2001 Bhuj, India, earthquake. http://preventionweb.net/go/2966. Accessed 16 Nov 2014.

Dai, F.C., C.F. Lee, and Y.Y. Ngai. 2002. Landslide risk assessment and management: An overview. Engineering Geology 64(1): $65-87$.

Du, G.M., S.W. Zhang, and Y.Q. Zhang. 2006. Character and causes of population distribution in Shenyang City, China. Chinese Geographical Science 16(3): 217-222.

Dunbar, P.K., R.G. Bilham, and M.J. Laituri. 2003. Earthquake loss estimation for India based on macroeconomic indicators. In Risk science and sustainability, ed. T. Beer, and A. Ismail-Zadeh, 163-180. Dordrecht: Springer. 
Elnashai, A.S., and J.F. Hajjar. 2006. Mid-America earthquake center program in consequence based seismic risk management. Paper presented at the 100th anniversary earthquake conference: Managing risk in earthquake country, at San Francisco, CA.

FEMA (Federal Emergency Management Agency). 2003. Multihazard loss estimation methodology-Earthquake model. In HAZUS-MH MR4: Technical Manual. Washington, DC: Department of Homeland Security.

Freire, S. 2010. Modeling of spatiotemporal distribution of urban population at high resolution-Value for risk assessment and emergency management. In Geographic information and cartography for risk and crisis management, ed. M. Konecny, S. Zlatanova, and L. Bandrova, 53-67. Berlin: Springer.

Freire, S., and C. Aubrecht. 2012. Integrating population dynamics into mapping human exposure to seismic hazard. Natural Hazards and Earth System Sciences 12(11): 3533-3543.

GEM (Global Earthquake Model). 2012. Open quake. GEM Foundation. http://beta.globalquakemodel.org/. Accessed 8 Jan 2013.

Hancilar, U., C. Tuzun, C. Yenidogan, and M. Erdik. 2010. ELER software-A new tool for urban earthquake loss assessment. Natural Hazards and Earth System Sciences 10(12): 2677-2696.

HBRI-BSTI (Housing and Building Research Institute and Bangladesh Standards and Testing Institution). 1993. Bangladesh National Building Code (BNBC), 1993. Dhaka.

Holt, J.B., C.P. Lo, and T.W. Hodler. 2004. Dasymetric estimation of population density and areal interpolation of census data. Cartography and Geographic Information Science 31(2): 103-121.

IDNDR (International Decade for Natural Disaster Reduction). 1999. RADIUS-risk assessment tools for diagnosis of urban areas against seismic disasters. UN-IDNDR. http://www.geohaz.org/ projects/radius.html. Accessed 30 May 2012.

Jaiswal, K.S., D.J. Wald, P.S. Earle, K.A. Porter, and M. Hearne. 2011. Earthquake casualty models within the USGS prompt assessment of global earthquakes for response (PAGER) system in human casualties in earthquakes: Progress in modelling and mitigation, ed. R. Spence, E. So, and C. Scawthorn. Dordrecht: Springer.

Jonkman, S.N., A. Lentz, and J.K. Vrijling. 2010. A general approach for the estimation of loss of life due to natural and technological disasters. Reliability Engineering \& System Safety 95(11): 1123-1133.

Jonkman, S.N., P.H.A.J.M. van Gelder, and J.K. Vrijling. 2003. An overview of quantitative risk measures for loss of life and economic damage. Journal of Hazardous Materials 99(1): 1-30.

Kerle, N. 2012. Remote sensing based post-disaster damage mapping with collaborative methods. In Intelligent systems for crisis management: Geo-information for disaster management (Gi4DM) 2012, ed. S. Zlatanova, P. Rob, D. Arta, and S. Hans, 121-133. Berlin: Springer.

Lang, S., D. Tiede, D. Hölbling, P. Füreder, and P. Zeil. 2010. Earth observation (EO)-based ex post assessment of internally displaced person (IDP) camp evolution and population dynamics in Zam Zam, Darfur. International Journal of Remote Sensing 31(21): 5709-5731.

Pulselli, R.M., P. Romano, C. Ratti, and E. Tiezzi. 2008. Computing urban mobile landscapes through monitoring population density based on cell-phone chatting. International Journal of Design \& Nature and Ecodynamics 3(2): 121-134.

Spence, R., and E. So. 2009. Estimating shaking-induced casualties and building damage for global earthquake events. Cambridge: National Earthquake Hazards Reduction Program.

Sutton, P., C. Elvidge, and T. Obremski. 2003. Building and evaluating models to estimate ambient population density. Photogrammetric Engineering and Remote Sensing 69(5): $545-553$.

UNDP (United Nations Development Programme)-Bangladesh. 2005. Beyond hartals: Towards democratic dialogue in Bangladesh. Dhaka: United Nations Development Programme.

UNISDR (United Nations International Strategy for Disaster Reduction). 2009. Terminology on disaster risk reduction. Geneva: United Nations International Strategy for Disaster Reduction.

Wu, S.S., X.M. Qiu, and L. Wang. 2005. Population estimation methods in GIS and remote sensing: A review. GIScience \& Remote Sensing 42(1): 80-96.

Zhang, Y., and N. Kerle. 2008. Satellite remote sensing for near-real time data collection. In Geospatial information technology for emergency response, vol. 6, ed. S. Zlatanova, and J. Li, 75-102. London: Taylor and Francis. 